\title{
Violence and migration: evidence from Mexico's drug war
}

\author{
Sukanya Basu* and Sarah Pearlman
}

\author{
* Correspondence: \\ subasu@vassar.edu \\ Vassar College, 124 Raymond \\ Avenue, Box 22, Poughkeepsie, NY \\ 12604, USA
}

\begin{abstract}
The effect of violence on people's residential choice remains a debated topic in the literature on crime and conflict. We examine the case of the drug war in Mexico, which dramatically increased the number of homicides since late 2006. Using data from the Mexican Census and labor force surveys, we estimate the impact of violence on migration at the municipal and state levels. To account for the endogeneity of violence, we use kilometers of federal highways interacted with cocaine supply shocks from Colombia as an instrument for the annual homicide rate. We argue that highways are good measures of pre-existing drug distribution networks, and the interaction with supply shocks arising in Colombia captures the time-variant nature of the value of these routes. After controlling for observed and unobserved area level heterogeneity, we find little evidence that increases in homicides have led to out-migration, at the domestic level. We also find little evidence of international migration at the municipal level, but some evidence of it at the state level. Our results show a muted migration response that is incompatible with a story of wide-scale displacement from the violence.
\end{abstract}

JEL Classification: $012, \mathrm{~K} 42, \mathrm{O} 54, \mathrm{~J} 11$

Keywords: Homicides, Migration, Drug distribution networks, Mexico, Conflict

\section{Introduction}

The impact of violence on the affected communities is not well understood and has recently become a topic of significant research in development and labor economics. In this paper, we study the impact of the drug war and the related steep rise in homicides since 2006 on the residential choices of the Mexican population. The drug war began after newly elected president Felipe Calderón launched a federal assault on drug trafficking organizations. Annual homicides increased from 10,452 in 2006 to 27,213 in 2011 (Trans-border Institute, 2012), and in total, more than 50,000 deaths are attributed to the conflict. ${ }^{1}$ The death toll also has been geographically concentrated, with only 3\% of municipalities accounting for $70 \%$ of homicides (Rios and Shirk 2011). Despite this regional concentration, the increased fear of violence has been widespread. Nationally representative victimization surveys show that the proportion of adults who feel their state of residence is unsafe rose $49 \%$ in 2004 to $61 \%$ in 2009 , and this increased feeling of insecurity occurred in states that did not become more violent as well as those that did. ${ }^{23}$ These distorted beliefs about the true level of violence have been found in other contexts (Becker and Rubinstein, 2011) and may play an important role in determining relocation decisions. ${ }^{4}$

(c) The Author(s). 2017 Open Access This article is distributed under the terms of the Creative Commons Attribution 4.0 International License (http://creativecommons.org/licenses/by/4.0/), which permits unrestricted use, distribution, and reproduction in any medium, provided you give appropriate credit to the original author(s) and the source, provide a link to the Creative Commons license, and indicate if changes were made. 
Hirschman (1970) states that one way for citizens to express their discontent if the advantages of being in an organization (here their residential location), and hence their loyalties, decrease is "exit", or migration to a more preferred location. Several papers have found that, at least on an aggregate level, people do exit locations when they think there is a threat of violent behavior, from governments or dissidents, to their "personal integrity" (Moore and Shellman 2004; Davenport et al. 2003). For example, in the case of the USA, Cullen and Levitt (1999) analyze the phenomenon of population flight from city centers to surrounding suburbs, and find that an increase in various crimes leads to a significant decline in cities' population. At an individual level, Dugan (1999) finds that individuals who are victims of property crime are significantly more likely to move, while Xie and McDowall (2008) find that victims of violent crime are also likely to move, and do so more than victims of property crime. They also find that, in addition to their own victimization, people react to a heightened fear of crime and move in response to the victimization of immediate neighbors.

Evidence of relocation also is found for Colombia, a country that, similar to Mexico, experienced a protracted conflict between the government, drug trafficking organizations, and rebel groups. Papers find that households with greater exposure to violence in their own or surrounding areas were more likely to move to safer metropolitan areas (Engel and Ibáñez, 2007), while households in major cities with higher kidnapping risks from rebel groups were likely to send members abroad (Rodriguez and Villa, 2012). The literature on Colombia also highlights that contrasted with traditional migration, risk aversion and lack of information may affect violence-induced migration (Engel and Ibáñez, 2007).

In contrast to Colombia, however, the increase in drug violence in Mexico was sharp and sudden. Over the 3-year period of 2006 to 2009, total homicides in Mexico rose by $90 \%$. In terms of a migration response, there are several anecdotal reports of people leaving areas that have been severely affected by the violence, with most accounts stating that migrants have moved across the border to the USA (Rice, 2011; Internal Displacement Monitoring Center, 2011; Arceo-Gómez, 2013). On a broad scale, however, almost no study has examined if the violence in Mexico led to widespread migration and subsequent population changes. One exception is Rios (2014), who finds that drug-related homicides are highly correlated with unpredicted population declines at the municipal level. Rios's identification strategy, however, is limited as it does not control for unobserved area level factors that may jointly determine drug violence and migration decisions. ${ }^{5}$ This omission is important as conflict can be linked with economic prosperity (Abadíe and Gardeazábal 2003), while socioeconomic factors at the area level can be significant determinants of displacement, even after conflict variables are controlled for (Verwimp et al. 2009). ${ }^{6}$

In this paper we overcome the obstacle of controlling for unobserved area level heterogeneity by using an instrumental variables strategy. We instrument for annual violence using kilometers of federal highways interacted with cocaine seizures in Colombia. We argue that highways capture pre-existing drug distribution networks and that the majority of violence has originated among cartels to gain control of these networks. Highways are a relevant predictor of the changes in local violence, but only after the start of the drug war. In order to account for time variation in the value of drug distribution routes and address concerns about the exclusion restriction-specifically the 
direct link between highways and migration-we interact highways with drug interdiction efforts from Colombia. Seizures changed during the drug war period and provided an external shock to the volume of drugs being transported across these routes (Castillo et al. 2016).

Overall, we find no strong evidence that increased homicides during the drug war period led to increased migration. For domestic migration, which arguably is less costly relocation, instead of the positive correlation between violence and relocation reported in previous papers and media reports, we find a negative relationship. Thus, once we account for unobservable area level or time-varying factors, we find that rising violence did not increase relocation, either across states or municipalities.

For international migration we find mixed results depending on the geographic level of aggregation. At the municipal level we find negative coefficients, showing that increased violence decreased the number of households that sent members abroad. At the state level, however, we find positive coefficients, suggesting the opposite. We argue these results may be a result of a heterogeneous response across municipalities in more violent states. In total, however, our results show a muted migration response to large increases in violence and one this is incompatible with a story of large-scale displacement. We propose that the results may be explained by multiple factors, including a low level of mobility among the Mexican population, perceptions of the differences in security in home and possible destination areas within Mexico, increases in the cost of relocation due to the violence itself, and adoption of alternate coping methods in response to violence.

\section{Theoretical framework}

In basic migration models, people or households choose to move by estimating the gain from migration, calculated as the difference in utilities at home $(h)$ and destination $(d)$ minus the cost of migration (C) (Borjas, 1987, 1999). People not only decide to migrate; they jointly decide where to migrate. Violence can indirectly influence the costs and benefits associated with a migration decision through many factors. First, violence impacts the perception of insecurity in the home and destination location. Individuals value security, and thus the perception of insecurity enters directly into the utility function. The perception of insecurity at home $\left(S_{i h}\right)$ is influenced by victimization, but also by the reports of violence in the neighborhood or even in adjoining municipalities. For example, people may live in small and relatively non-violent municipalities, but their states may be violent. As a result, the perception that violence can spill over to their municipality in the future can cause people to move in the present.

The perception of insecurity in the destination area can differ depending on whether the migration decision is domestic or international. This is an important consideration in the case of Mexico, since the high rates of migration to the USA mean that potential movers likely simultaneously consider relocating either to the USA or elsewhere in Mexico (Aguayo-Téllez and Martínez-Navarro, 2012). If a country in its entirety is believed to be unsafe, a household may be more compelled to move abroad. For example, Wood et al. (2010) find that the increase in crime in the 1980s that plagued most of Latin America increased the probability that people in the region intended to move their entire household to USA. Individuals may believe longer distances increase their safety, and distance can be artificially inflated by the presence of national borders. 
Second, violence can impact the economic well-being of an individual, by affecting a household's human capital and financial investment decisions and local labor market outcomes. For example, drug violence is seen to negatively impact school attendance and grades of children in Mexico (Michaelsen and Salardi, 2015; Orraca Romano, 2015). ${ }^{7}$ For financial investment, there is limited evidence connecting savings increases and violent crimes, but some evidence in Brazil that property crime makes households thrifty (De Mello and Zilberman 2008). For labor markets, Robles et al. (2013) and Velásquez (2015) find negative effects on local labor force participation and employment from marginal increases in violence in the Mexican context. On the other hand, drug gangs themselves may provide employment opportunities to local residents. These jobs may be more appealing if a gang controls an area, effectively becoming a local monopoly or if jobs in the legitimate sector are scarce or of lower pay. Finally, violence can lead to the threat of expropriation of property and increase tenure insecurity. The lack of well-defined property rights is seen to lock Mexican people to their land, and reduce international migration (Valsecchi, 2014). Criminal vandalism and violent crimes also have a negative impact on housing prices in an area, reducing incentives to move (Gibbons, 2004; Ihlanfeldt and Moyock 2010). If these factors outweigh the insecurity from violence, we may find no out-migration in areas with greater cartel presence.

Third, violence may increase migration costs. Cartels aiming to dominate an area can try to prevent residents from moving. For instance, the Congressional Research Service Report for Congress (2013) points out cases where cartels either massacred migrants who were crossing the border, or tried to force migrants to move drugs across the border on their behalf.

Combining these factors, a person $(i)$ decides to move if the differences in the expected utility from the destination and home location are larger than the cost of migrating. Expected utility from a respective location is a function of wages $(w)$, local amenities $(Z)$, other individual characteristics, such as wealth and fixed assets $(I)$, and perceptions of insecurity $(S)$ :

$$
U\left(w_{i d}, I_{i d}, Z_{i d}, S_{i d}\right)-U\left(w_{i h}, I_{i h}, Z_{i h}, S_{i h}\right)-C_{i}>0
$$

The equation above highlights that a person moves if the perceived differences in safety and economic outcomes outweigh the cost. An individual therefore may remain in a location if the perceived gains in safety from the home to destination area or if the perceived differences in economic outcomes are sufficiently small. Several papers provide examples when both have been the case. Morrison (1993) finds that economic factors dominate violence as determinants of migration in Guatemala during the country's civil war, while both Morrison (1993) and Bohra-Mishra and Massey (2011) find that people are less likely to move at low and moderate levels of violence. Only at high levels of violence do individuals move. People may instead adjust to violence in alternative ways. For example, Braakmann (2012) shows that within-community differences in victimization risk in Mexico induce behavioral changes among individuals in terms of work-leisure time allocation and property protection. Alvarado and Massey (2010) examine the effect of structural adjustment and violence on migration from selected countries in Latin America, including Mexico, and find that increased homicides reduce the likelihood of out-migration to the USA. 
Finally, it is important to note that in the empirical analysis that follows we focus on the push factor $S_{i h}$, or violence in the origin area, rather than the pull factor, or the relative violence in the destination area. We do this as, we detail below, for most of our data we do not have information on the specific destination of relocation, making it impossible to use destination area variables. Even if we had destination information, the salient variable is security at potential destinations, which is unobservable in most cases. Specifically, potential destination is a latent variable that is observed if a person moves and unobserved if not. This leads to concerns over omitted variables bias if we were to use a measure of relative homicides between the origin and destination locations. To avoid this problem, we only consider homicides in the origin location.

\section{Data}

\subsection{Homicide data}

To measure violence from the drug war, we use data on intentional homicides from municipal death records, compiled and made publicly available by the National Statistical and Geographical Institute (Instituto Nacional de Estadística y Geografía, or INEGI). ${ }^{89}$ From this we construct an annual homicide rate per 100,000 inhabitants for origin region $j$ using annual population data from the National Council on Population (CONAPO). ${ }^{10}$ For comparison we also construct an 195 aggregated measure of violence over the drug war period under study. We calculate 196 total homicides from January 2007 to December 2010 and convert this to a homicide 197 per 100,000 inhabitants as of 2005.

Summary statistics for municipal- and state-level values are shown in Table 1 . The sharp rise in homicides following the beginning of the federal crackdown on drug cartels in late 2006 is apparent. As shown in panel A, at the municipal level homicides per 100,000 inhabitants rise from an average of 10.87 in 2005 to 21.24 in 2010-an increase of 98\%, while the maximum jumps from 325 in 2005 to 847 in 2010 -an increase of $160 \%$. We see similar results at the state level in panel B. Average homicides rise from 8.7 in 2005 to 25.9 in 2010 - an increase of $198 \%$-while the maximum increases over $800 \%$.

The table also shows the growing disparity across areas in levels of violence following the start of the drug war. From 2005 to 2010 the standard deviation in homicides across municipalities increases more than 100\%, while at the state level it increases more than $600 \%$. The concentration of violence geographically also is evident from municipal and state maps, shown in Fig. 1. To capture violence over the drug war period under study, these maps present homicides over the 20072010 period per 100,000 inhabitants. As shown in panel (a) of Fig. 1, the majority of municipalities in Mexico have not exhibited high levels of homicides. Instead, a small number of municipalities exhibit high levels of both. The lower panel (b) shows a similar phenomenon at the state level. ${ }^{11}$ Figure 1 also shows an absence of regional concentration in terms of where the most violent municipalities or states are located. The most violent areas are not exclusively along the US border, and several are along the Pacific and Gulf Coasts. This highlights that the intensity of the drug war is not wholly determined by proximity to the USA. ${ }^{12}$ 
Table 1 Summary statistics: homicides

\begin{tabular}{|c|c|c|c|c|c|c|c|c|}
\hline \multirow[t]{2}{*}{ PANEL A: municipal level } & \multirow{2}{*}{$\begin{array}{l}\text { Sum } \\
2007-2010\end{array}$} & \multicolumn{6}{|c|}{ Totals by year } & \multirow[t]{2}{*}{ All years } \\
\hline & & 2005 & 2006 & 2007 & 2008 & 2009 & 2010 & \\
\hline Mean & 58.91 & 10.87 & 11.4 & 10.03 & 12.95 & 16.35 & 21.24 & 13.8 \\
\hline Standard deviation & 93.9 & 22.61 & 24.51 & 19.82 & 30.49 & 35.17 & 49.42 & 32.15 \\
\hline Minimum & 0 & 0 & 0 & 0 & 0 & 0 & 0 & 0 \\
\hline Maximum & 2068.89 & 325.73 & 567.64 & 304.88 & 609.76 & 938.8 & 847.46 & 938.8 \\
\hline 25th percentile & 12.37 & 0 & 0 & 0 & 0 & 0 & 0 & 0 \\
\hline 50th percentile & 31.93 & 3.42 & 3.69 & 2.86 & 4.44 & 6.86 & 6.49 & 4.55 \\
\hline 75th percentile & 65.43 & 12.85 & 13.7 & 11.17 & 14.33 & 18.09 & 19.71 & 14.83 \\
\hline 90th percentile & 145.62 & 27.48 & 29.76 & 28.36 & 32.22 & 41.94 & 57.17 & 34.92 \\
\hline \multirow[t]{2}{*}{ Panel B: state level } & Sum & \multicolumn{6}{|c|}{ Totals by year } & \multirow[t]{2}{*}{ All years } \\
\hline & 2007-2010 & 2005 & 2006 & 2007 & 2008 & 2009 & 2010 & \\
\hline Mean & 68.8 & 8.69 & 9.01 & 8.14 & 13.31 & 19.13 & 25.9 & 15.81 \\
\hline Standard deviation & 75.56 & 4.97 & 6.09 & 4.85 & 14.01 & 22.48 & 35.33 & 21.05 \\
\hline Minimum & 9.09 & 2.02 & 2.22 & 2.56 & 2.42 & 1.82 & 1.8 & 1.79 \\
\hline Maximum & 396.38 & 18.7 & 24.77 & 23.87 & 75.21 & 105.97 & 183.31 & 183.31 \\
\hline 25th percentile & 27.32 & 4.81 & 4.36 & 4.74 & 5.66 & 7.42 & 7.03 & 5.96 \\
\hline 50th percentile & 40.71 & 6.47 & 6.64 & 6.37 & 7.95 & 10.22 & 14.27 & 9.45 \\
\hline 75th percentile & 71.77 & 13.04 & 12.16 & 10.98 & 16.16 & 18.64 & 27.92 & 16.67 \\
\hline 90th percentile & 158.67 & 16.98 & 18.54 & 15.21 & 31.47 & 55.12 & 52.78 & 27.97 \\
\hline
\end{tabular}

Source: INEGI. The all years, annual summary statistics at the state level are for years 2005-2011

\subsection{Migration data}

Our theoretical framework considers individual migration decisions, but in the analysis that follows we create gross migration rates at the area level. We do this since we do not know individual's perceptions of security, and use actual violence at an area level as a proxy. We therefore examine the impact of violence in an origin area on the migration decisions of people already in those areas.

The first source of data is the 2010 Mexican Census, as accessed through IPUMS International, maintained by Population Center at the University of Minnesota. The Census is the only data set that is representative at the municipal level and provides information on domestic and international migration. For domestic migration the survey asks the current municipality of residence and the municipality of residence 5 years ago (in the year 2005). We record someone as a national migrant if they are older than five, lived in Mexico in 2005, and live in a different municipality in 2010 than in $2005 .{ }^{13}$ Movements across or within states are counted equally, as the goal is to capture the sheer number of people relocating during the drug war. The Census measure creates a 5-year domestic migration rate from 2005 to 2010.

For international migration the Census includes a module that asks households if a member has moved abroad in the past 5 years and, if so, the exact year of their departure. We use this information to count all individuals over the age of five, who lived in Mexico in 2005, and are reported to have moved between 2005 and 2010. It is important to note that this measure likely is a lower bound on the true incidence of international migration, as individuals who moved abroad with their entire household are not included. 


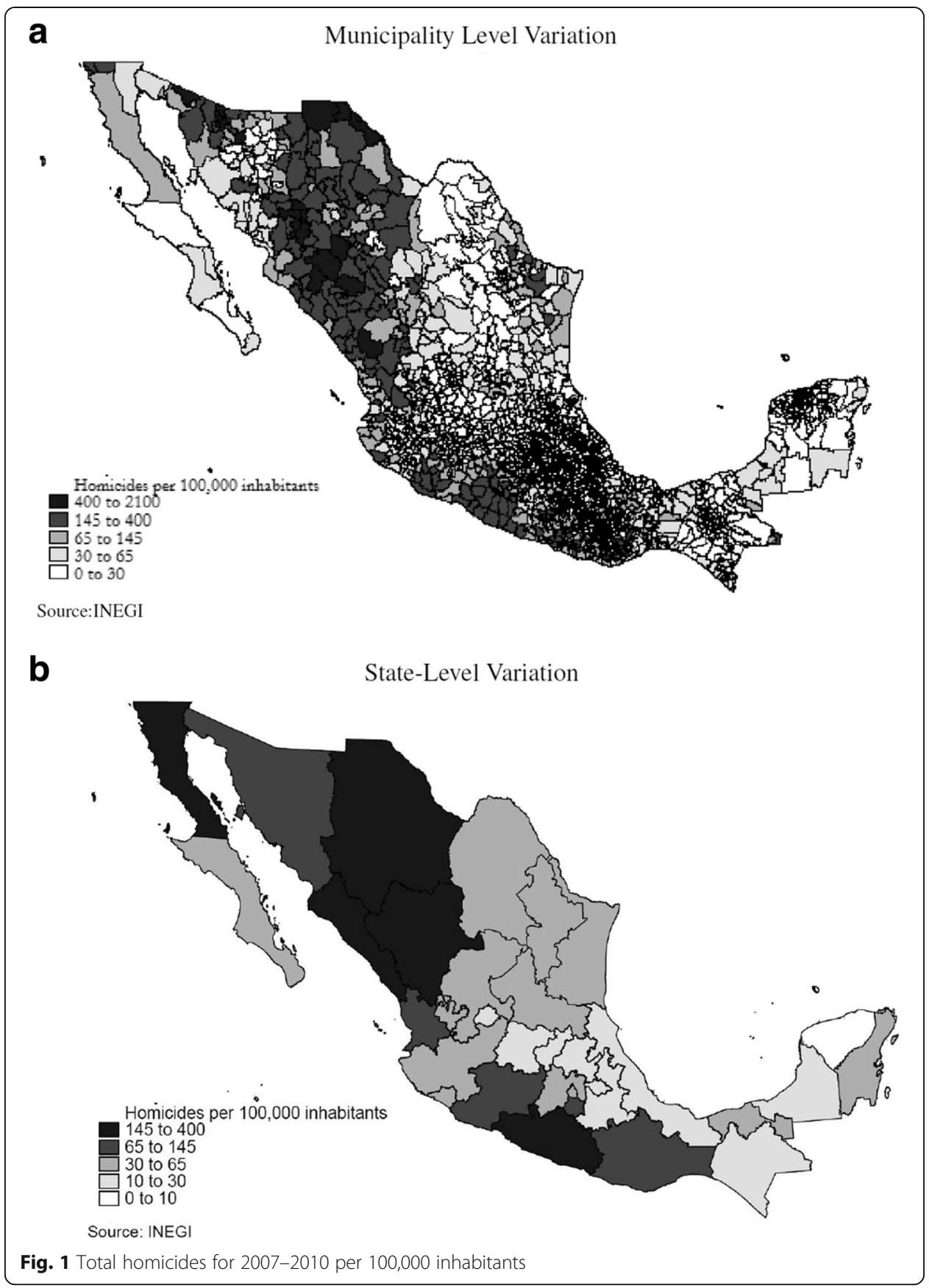

The benefit of the Census is that it is representative at the municipal level, giving us a finer degree of geographic variation. The downside, however, is that individuals are not asked about the timing of their domestic relocation; hence, annual measures of municipal-level domestic migration cannot be constructed. As we detail in the next section, time variation is important for the identification assumptions of our empirical model. We therefore turn to a second data source, the National Survey of Occupation and Employment (referred to by its Spanish acronym ENOE). ${ }^{14}$ The ENOE is a rotating panel that surveys households for five consecutive quarters, is representative at the 
state level (not the municipal level), and keeps track of all members listed in the initial survey. ${ }^{15}$ To create annual flows, we restrict attention to households who enter the sample in the first quarter of a given year, and record an individual as a national migrant if they are reported as (a) moving to another state or (b) moving within or to another state (anywhere else in Mexico) in any of the subsequent four quarters. The former is more likely to capture costlier internal migration, while the latter also includes less costly migration in the form of moving, for example, to another neighborhood in the same city. We count individuals as international migrants if they are reported as moving abroad in any of the subsequent four quarters. The ENOE therefore captures short-term migration, as it measures the number of individuals in a given state who move between the first quarter of a given year and the first quarter of the next year. Like the Mexican Census, the ENOE also may undercount the number of domestic and international migrants, since entire households that move cannot be identified.

We calculate gross migration rates by taking the total number of individuals who moved either domestically or abroad and dividing by the population in a given area at the beginning of the period. All of the migration totals are calculated using population weights. We calculate a gross rather than a net migration rate as we do know where people move to domestically in the ENOE-our main data source for migrationmaking it impossible to calculate inflows. ${ }^{16}$

Summary statistics on 5-year aggregate and annual gross migration rates are provided in Table 2. Panels A and B contain measures of national and international migration, respectively. We re-iterate that the municipal-level measures come from the Mexican Census, while the state-level measures are from the ENOE. ${ }^{17}$ Two conclusions emerge from Table 2. First, panel A shows that domestic migration rates in Mexico are low. In 2010 the average 5-year national migration rate was 4.15\%. Meanwhile, over the

Table 2 Summary statistics: migration

\begin{tabular}{|c|c|c|c|c|c|c|c|}
\hline \multicolumn{8}{|c|}{ Panel A: national migration } \\
\hline & Municipal level & \multicolumn{6}{|c|}{ State level, by year } \\
\hline & 2005-2010 Period & 2005 & 2006 & 2007 & 2008 & 2009 & 2010 \\
\hline Mean across areas & $4.15 \%$ & $0.31 \%$ & $0.29 \%$ & $0.32 \%$ & $0.32 \%$ & $0.29 \%$ & $0.27 \%$ \\
\hline Standard deviation & $(0.067)$ & $(0.002)$ & $(0.002)$ & $(0.002)$ & $(0.002)$ & $(0.001)$ & $(0.001)$ \\
\hline
\end{tabular}

Panel B: international migration

\begin{tabular}{llllllll} 
& Municipal level & \multicolumn{7}{l}{ Municipal level, by year } \\
& $2005-2010$ Period & 2005 & 2006 & 2007 & 2008 & 2009 & 2010 \\
Mean across areas & $1.50 \%$ & $0.18 \%$ & $0.33 \%$ & $0.34 \%$ & $0.32 \%$ & $0.29 \%$ & $0.25 \%$ \\
Standard deviation & $(0.015)$ & $(0.002)$ & $(0.003)$ & $(0.003)$ & $(0.004)$ & $(0.004)$ & $(0.004)$ \\
& State level & State level, by year & & & & \\
& $2005-2010$ Period & 2005 & 2006 & 2007 & 2008 & 2009 & 2010 \\
Mean across areas & $2.71 \%$ & $0.22 \%$ & $0.22 \%$ & $0.16 \%$ & $0.14 \%$ & $0.11 \%$ & $0.09 \%$ \\
Standard deviation & $(0.023)$ & $(0.002)$ & $(0.001)$ & $(0.001)$ & $(0.001)$ & $(0.001)$ & $(0.001)$ \\
\hline
\end{tabular}

Municipal level obs. $=2455$. State level obs. $=32$

Municipal level data are from the 2010 Mexican Census. State level data are from annual ENOE surveys

We also compare state level international migration rates from the Census and ENOE. For the 2005-2010 period, the total international migration at the state level from the Census is $3.11 \%$, slightly higher than the ENOE total. Across all states the correlation between the Census \& ENOE 5-year international migration rates is $92.1 \%$. For annual international migration rates, correlation between the census and the ENOE is $56.6 \%$

Source: Mexican Census, as accessed through IPUMS, and the ENOE 
previous 10-year period (1995 to 2000), the national migration rate is 5.48\%. These numbers are lower than comparable countries and highlight that the Mexican population is less mobile than populations used in other studies of relocation responses to violence. For example, over the 2000-2005 period, the 5-year migration rate for Argentina, Brazil, Ecuador, and Honduras were 7.2, 10, 8.3, and 7.2\% respectively (Bell and Muhidin, 2009). Finally, for Colombia, a country that also suffered from drug violence, the 5-year migration rate from 2005 to 2010 was 7.4\% (Bell and Muhidin, 2009) - more than three percentage points higher than Mexico for the same period.

Second, the table shows the decline in international migration rates from 2005 to 2010. This is strongly seen in the state-level rates, which fall from $0.22 \%$ in 2005 to $0.09 \%$ in 2010. This decline in international migration, specifically to the USA, is thought to be the result of reduced job opportunities in the USA, improved job opportunities in Mexico and increased border enforcement (Passel et al. 2012). This suggests there were multiple forces acting to reduce international migration during the drug war period.

\section{Estimation strategy}

4.1 Instrumental variable: rationale and relevance

The migration rate of area $j$ in period $t$ can be outlined as a linear function of area homicides per 100,000 inhabitants during the same time period, observable area level characteristics $\left(M_{j}\right)$, time fixed effects $\left(\delta_{t}\right)$, and unobservable area level and timeperiod-specific characteristics $\left(\varepsilon_{j, t}\right)$.

$$
\text { MigrationRate }_{j, t}=\beta_{1}+\beta_{2} \text { Homicides }_{j, t}+\gamma M_{j}+\delta_{t}+\varepsilon_{j, t}
$$

The challenge to identifying $\beta_{2}$ stems from the existence of unobserved characteristics that may jointly determine migration decisions and homicides. Ex ante, it is unclear what bias these characteristics may exert. On one side, factors such as institutions may put upward bias on the coefficient, if areas with weak institutions experience a larger increase in violence due to less effective police and judicial services and greater outmigration if employers and job opportunities locate elsewhere. On the other side, factors such as the effectiveness of drug trafficking organizations may put downward bias on the coefficient if these organizations create more job opportunities-reducing the incentives to migrate-but also increase levels of violence.

To control for unobserved heterogeneity, we instrument for area homicides in period $t$ using kilometers of federal highways interacted with quantity of cocaine seized by Colombian authorities in the same period. In this section, we outline the rationale behind this interacted variable and separately discuss each part of the instrument.

We begin with a discussion regarding the use of highways. First, the beginning of the drug war coincides with the federal government crackdown on drug trafficking organizations, which began in December of 2006. This is apparent by looking at the summary statistics in Table 1, but also has been documented by Dell (2015), who examined the impact of government crackdowns on drug trafficking. She finds that violence increased most sharply in areas where the government directly confronted drug trafficking organizations. Other potential explanations for the violence, including increased political competition that changed implicit agreements between the government and cartels, Mexico taking Colombia's place as the major distributor of 
drugs to the USA, and changes in relative prices which increased the production of marijuana and opium within Mexico (Dube et al. 2014), either pre-date the conflict by many years or cannot be timed exactly to late $2006 .{ }^{18}$ These factors may work in conjunction with the government crackdown to explain the perpetuation of violence after 2007; however, in isolation they cannot explain the timing of the increase.

The government crackdown on the cartels entailed the capture and killing of members of drug trafficking organizations and the seizure of drugs and weapons (Guerrero-Gutiérrez, 2011). In doing so the government weakened previously oligopolistic organizations, leading to turf wars as organizations fought for control of the drug production and distribution networks of their weakened rivals. One argument is that increased competition was most severe over access to distribution networks-and specifically land transport routes-to the USA, the largest drug consumer market in the world and Mexico's largest trading partner for legal goods (Rios 2012, Dell 2015). Arguably, areas with more access to distribution routes should experience the largest increases in violence.

This leads to the second part of the logic that includes federal highways in the instrument-namely, highways capture distribution networks to the USA. First, the majority of transport of goods and people from Mexico to the USA occurs via highway. The North American Transportation Statistics Database indicates that in 2011, approximately 65\% of Mexican exports to the USA were transported via highway, while $82 \%$ of Mexican travel to the USA occurred via highways and rail. ${ }^{19}$ Second, federal highways are the highest quality road routes, with more stretches of paved roads and roads with four, as opposed to two, lanes. Federal highways, particularly the toll ones, frequently are the fastest and easiest way to travel between areas in Mexico. Third, the federal highway system includes the most transited and valuable routes, many of which run to and cross the US border. ${ }^{20}$ For example, the federal highway system has seven crossing points into the USA, as compared to only one crossing point into Mexico's southern neighbor, Guatemala. Finally, the U.S. Department of Justice (2010) estimates that most drugs are smuggled into the USA via land routes using commercial or private vehicles, and these are then transported across the USA using highways. ${ }^{21}$ It therefore is very likely that many drug shipments are transported through Mexico using the same routes as legal goods and the routes used within the USA.

To ensure that more recent factors linked to homicide rates and migration do not determine highway placement, we use federal highway values from 2005-which predates the drug war. We then test the hypothesis that highways are a relevant predictor of homicides during the drug war period, by regressing homicides per 100,000 inhabitants on federal highway kilometers in 2005 for each year in the 2000 to 2010 period. Results for municipalities are shown in panel A of Table 9 in Appendix, while results for states are shown in panel B. The results show a clear relationship between highways and homicides, but only after the drug war begins. At the municipal level, the coefficients on federal highways in years prior to 2008 are insignificant, while at the state level they are insignificant prior to 2006. After the drug war begins, federal highways became a positive and significant predictor of homicides. Furthermore, the strength of this relationship increases over time, with the largest coefficients found in 2010. Hence, areas with more federal highways indeed became more violent over time. 
The problem with using highways alone is that the exclusion restriction, which assumes that federal highways do not directly affect migration rates, may not hold. First, highways influence the transportation costs associated with migration to or from certain areas, which will directly affect migration rates. Second, though we use highway values from 2005 that pre-date the Great Recession and the drug war, highways might capture changes in economic activity due to linkages to the USA which could affect both homicides and migration across Mexican locations. For instance, areas that suffered more during the recession may exhibit higher migration rates, but also greater increases in violence, if drug trafficking organizations are better able to recruit members, expand their operations, and challenge rivals in these same areas. In this case federal highways may be directly correlated with our outcome variable, violating the exclusion restriction.

We therefore employ an instrumental variable that exploits time variation to capture the portion of transportation networks not directly related to migration. Specifically, following Castillo et al. (2016) we use changes to the quantity of cocaine being shipped from Colombia to Mexico to capture variation in the value of drug distribution networks to the USA over time. Unlike other drugs that reach the USA from Mexico, such as marijuana or heroin, cocaine is not produced in Mexico. All of the cultivation of coca leaves, the main input into cocaine, and the refinement of these leaves into cocaine occurs in three countries: Peru, Bolivia, and Colombia (UNODC World Drug Report 2010), with Colombia being the dominant producer. According to the 2013 United Nations World Drug Report, Colombia was responsible for 54\% of all coca cultivation and $61 \%$ of all cocaine production in 2007. These numbers remain high despite a large-scale anti-drug policy enacted by Colombian authorities in the late 1990s. ${ }^{22}$ Furthermore, cocaine distribution is estimated to make up the majority of revenues generated by Mexican drug trafficking organizations. Specifically, cocaine distribution is estimated to account for $45-68 \%$ of all revenues of Mexico drug trafficking organizations (Kilmer et al. 2010). This is more than twice the estimated revenues from the distribution of marijuana, more than eight times the estimated revenues from heroin produced in Mexico, and more than five times the estimated revenues from methamphetamines produced in Mexico (Kilmer et al. 2010). ${ }^{23}$

The amount of cocaine reaching Mexican borders partially depends on the efforts of Colombian authorities to combat drug trafficking, and specifically, their efforts to seize cocaine supplies. In recent years Colombia has increased its interdiction efforts, leading to greater external shocks to the supply of cocaine reaching Mexico (see Castillo et al. 2016 for details). These shocks likely alter the use of highways to transport drugs to the USA, and have been documented to increase violence in areas contested by Mexican drug trafficking organizations (Castillo et al. 2016). To measure these external shocks, we use data from the Colombian Defense Ministry on tons of cocaine seized by Colombian authorities in each year. ${ }^{24}$ These totals are presented in panel A of Figure 3 in Appendix, and show no clear upward or downward trajectory over the drug war period. Thus the cocaine seizures do not appear to be capturing a parallel time trend to that of homicides over the time period considered.

We provide several tests of the assumption that seizures capture changes in the supply of drugs being transported through Mexico but are uncorrelated with events in the USA or Mexico that may impact migration. First, we find no positive correlation 
between Colombian cocaine seizures and migration to the USA, as measured by the number of new Mexican immigrants captured in the American Community Survey (ACS). As seen in panel B of Figure 3 in Appendix, the relationship between seizures and immigration is negative, even after the drug war begins. This suggests cocaine seizures are not directly associated with a rise in Mexican migration to the USA. We also estimate the relationship between monthly cocaine seizures in Colombia and monthly trade flows of "legal goods" using measures of exports from the IMF Direction of Trade Statistics over the period of January 2004 (first available in DOTS) to April 2012. As shown in panel A of Table 10 in Appendix, there is no significant relationship between cocaine seizures in Colombia and (1) bilateral trade flows between Colombia and Mexico, (2) bilateral trade flows between the USA and Colombia, (3) trade flows between Colombia and the rest of the world, (4) bilateral trade flows between the USA and Mexico, and (5) trade flows between Mexico and the world. This provides evidence that cocaine seizures are not correlated with other trade activity.

We also examine the relationship between cocaine seizures and employment rates, unemployment rates, weekly hours worked for those who are employed, and real GDP. ${ }^{25}$ We use quarterly variables to increase the time variation used to estimate the correlations and show the results in panel B in Table 10 in Appendix. We find no significant correlation between any of the variables, which suggests that cocaine seizures from Colombia do not affect migration through impacts on labor market activity or legal economic activity, more generally.

Finally, we examine the relationship between Colombian cocaine seizures and seizures of opium and marijuana by Mexican authorities, using data obtained from the Mexican Ministry of Defense (SEDENA). The results of this analysis are shown in panel $\mathrm{C}$ in Table 10 in Appendix. We find no significant correlation between Colombian cocaine seizures and seizures of either opium or marijuana. This suggests a reduction in cocaine arriving in Mexico did not coincide with increased seizures of other drug cartel transport.

\subsection{The model}

Our instrument is the interaction of kilometers of federal highways in the year 2005 with thousands of tons of cocaine seized by Colombian authorities each year. The identification assumption is that shocks to cocaine supplies impact the value of highways for drug transport and violence related to control of these routes, but have no direct effect on migration.

The first stage of our instrumental variables model is the following:

$$
\begin{aligned}
\text { Homicides }_{j, t}= & \alpha_{1}+\alpha_{2}\left(\text { FederalHighwayKilometers }_{j}^{2005} * \text { CocaineSeizures }_{t}\right) \\
& +M_{j}^{\prime} \theta+\delta_{t}+e_{j t}
\end{aligned}
$$

The second stage is:

$$
\text { MigrationRate }_{j, t}=\beta_{1}+\beta_{2} \text { Homicides }_{j, t}+M_{j}^{\prime} \gamma+\delta_{t}+\varepsilon_{j, t}
$$

where Homicides $\hat{j}_{j, t}$ are fitted values from the first stage regression.

To estimate the model we use panel data on international migration at the municipal level from the Census and panel data on domestic and international migration at the 
state level from labor force surveys. For comparison to previous studies, we also include results from cross-sectional data on domestic and international migration from the Census. For the Census we have annual data on the 2005 to 2010 period, while for the ENOE we have data from the 2005 to 2011 period. The outcome variable is homicides per 100,000 inhabitants in area $j$ in time period $t$. This is a function of the instrument, time-invariant area characteristics $\left(M_{j}\right)$, time period fixed effects $\left(\delta_{t}\right)$, and unobservable area-year factors $\left(\varepsilon_{j, t}\right)$.

Given the small number of time periods in our sample, our first stage relies heavily on cross-sectional variation to identify a relationship between the instrument and homicides. As a result, we do not include state or municipal fixed effects in our regressions. In their place we include observable state and municipal characteristics, detailed shortly. We recognize concerns about the absence of geographic fixed effects, and address these in Section 6.2. At both the state and municipal levels, we include controls for economic activity and wealth. At the state level we use annual real GDP and unemployment rates. At the municipal level, since we do not have annual data or GDP values, we use unemployment rates in 2010 and 2000, average years of education for adults, the percentage of households with running water, and household income per capita in the year 2000. We also account for pre-existing levels of violence by including average homicides per 100,000 inhabitants for the years 2003 and 2004. To account for time-invariant migration costs, we include all non-federal (state) highways as of 2005. A larger highway network should reduce the cost of moving elsewhere in Mexico and abroad, but these costs likely are general to the entire highway network, rather than specific to federal highways. ${ }^{26}$ Thus our instrument captures changes in the value of the drug distribution routes conditional on the pre-existing local transportation network. Finally, we include population density to account for the possibility that both homicide and migration rates are higher in urban areas. ${ }^{27}$

\section{Results}

The first stage results from the instrumental variables model are shown in Table 3. The second stage IV results for domestic migration are shown in Table 4, while the second

Table 3 First stage results

\begin{tabular}{llll}
\hline Geographic variation: & \multicolumn{1}{l}{ Municipal level } & & State level \\
\cline { 2 - 3 } Data & Panel & Cross section & Panel \\
\hline Outcome: homicides per 100,000 inhabitants & $(1)$ & $(2)$ & $(3)$ \\
Federal highway kilometers 2005* & $0.27267^{* * *}$ & & $0.03938^{* * *}$ \\
Cocaine seizures in Colombia & $(0.07931)$ & $0.24475^{* * *}$ & $(0.01237)$ \\
Federal highway kilometers 2005 & & $(0.04914)$ & 224 \\
Observations & & 2425 & 10.13 \\
Angrist-Pischke F value & 14,268 & 24.81 & 10.26 \\
Anderson-Rubin LM ChiSquared value & 11.82 & 24.66 & \\
\hline
\end{tabular}

Robust standard errors in parentheses. ${ }^{* *} p<0.01,{ }^{* *} p<0.05,{ }^{*} p<0.1$

Municipal controls include average homicides from 2003 to 2004, population density, average years of schooling, \% of $\mathrm{HHs}$ with running water, unemployment in 2010 and 2000, income per capita in 2000, kilometers of state highways in 2005 , and year fixed effects for the panel. State controls include average homicides from 2003 to 2004, population density, annual real GDP per capita and unemployment, non-federal highways in 2005 and year fixed effects Source: Mexican Census, as accessed through IPUMS, ENOE, INEGI, Colombian Ministry of Defense 
Table 4 OLS and second stage IV results: domestic migration

\begin{tabular}{|c|c|c|c|c|c|c|}
\hline \multirow{3}{*}{$\begin{array}{l}\text { Geographic variation: } \\
\text { Data: } \\
\text { Model: }\end{array}$} & \multirow{2}{*}{\multicolumn{2}{|c|}{$\begin{array}{l}\text { State level } \\
\text { Panel (another state) }\end{array}$}} & \multirow{2}{*}{\multicolumn{2}{|c|}{$\begin{array}{l}\text { State level } \\
\text { Panel (anywhere in Mexico) }\end{array}$}} & \multirow{2}{*}{\multicolumn{2}{|c|}{$\begin{array}{l}\text { Municipal level } \\
\text { Cross section }\end{array}$}} \\
\hline & & & & & & \\
\hline & \multirow{2}{*}{$\begin{array}{l}\text { OLS } \\
\text { (1) }\end{array}$} & \multirow{2}{*}{$\begin{array}{l}\text { IV } \\
(2)\end{array}$} & \multirow{2}{*}{$\begin{array}{l}\text { OLS } \\
\text { (3) }\end{array}$} & \multirow{2}{*}{$\begin{array}{l}\text { IV } \\
(4)\end{array}$} & OLS & IV \\
\hline & & & & & (5) & (6) \\
\hline \multirow{2}{*}{$\begin{array}{l}\text { Annual homicides, } \\
\text { per 100,000 inhabitants }\end{array}$} & $-0.00085^{* *}$ & $-0.00954^{* *}$ & -0.00206 & -0.01405 & & \\
\hline & $(0.00038)$ & $(0.00391)$ & $(0.00200)$ & $(0.00889)$ & & \\
\hline \multirow{2}{*}{$\begin{array}{l}\text { Homicides } 2007-2010 \\
\text { per } 100,000 \text { inhabitants }\end{array}$} & & & & & $0.00228^{* * *}$ & 0.00596 \\
\hline & & & & & $(0.00088)$ & $(0.00772)$ \\
\hline Observations & 224 & 224 & 224 & 224 & 2425 & 2425 \\
\hline
\end{tabular}

Robust standard errors in parentheses

${ }^{* * *} p<0.01,{ }^{* *} p<0.05,{ }^{*} p<0.1$

stage IV results for international migration are shown in Table 5. To show the extent to which unobserved area level heterogeneity may bias the results we also estimate all models via OLS. For ease of interpretation we re-scale the migration rates by multiplying by 100 (thus a migration rate of $1.5 \%$ becomes 1.5 ). These results are presented alongside the second stage IV results in Table 4. All coefficients are population weighted. Standard errors are shown in parentheses. ${ }^{28}$

\subsection{First stage results}

The results of the first stage IV regressions in Table 3 show that the strong relationship between federal highways and homicides remains after we control for area level characteristics. In all cases the coefficients on the instrument are large and significant. For example, the coefficient in column 1 implies that a one standard deviation increase in federal highways $(48 \mathrm{~km})$ is associated with a rise in homicides per 100,000 inhabitants of 13.1 - approximately $40 \%$ of a standard deviation. The Anderson-Rubin LM $\chi^{2}$ value and Angrist-Pischke $F$ values are sufficiently high to reject the respective nulls of an under-identified model and an identified model that suffers from a weak correlation

Table 5 OLS and second stage IV results: international migration

\begin{tabular}{|c|c|c|c|c|c|c|}
\hline \multirow{3}{*}{$\begin{array}{l}\text { Geographic variation: } \\
\text { Data: } \\
\text { Model: }\end{array}$} & \multirow{2}{*}{\multicolumn{2}{|c|}{$\begin{array}{l}\text { State level } \\
\text { Panel }\end{array}$}} & \multicolumn{4}{|c|}{ Municipal level } \\
\hline & & & \multicolumn{2}{|l|}{ Panel } & \multicolumn{2}{|l|}{ Cross section } \\
\hline & OLS & IV & OLS & IV & OLS & IV \\
\hline & (1) & (2) & (3) & (4) & (5) & (6) \\
\hline \multirow{2}{*}{$\begin{array}{l}\text { Annual homicides, } \\
\text { per 100,000 inhabitants }\end{array}$} & 0.00016 & $0.00482^{* *}$ & -0.00009 & $-0.00605^{* * *}$ & & \\
\hline & $(0.00028)$ & $(0.00245)$ & $(0.00012)$ & $(0.00203)$ & & \\
\hline \multirow{2}{*}{$\begin{array}{l}\text { Homicides } 2007-2010 \\
\text { per } 100,000 \text { inhabitants }\end{array}$} & & & & & $-0.00106^{* * *}$ & $-0.00568^{*}$ \\
\hline & & & & & $(0.00037)$ & $(0.00340)$ \\
\hline Observations & 224 & 224 & 14,268 & 14,268 & 2425 & 2425 \\
\hline
\end{tabular}

Robust standard errors in parentheses

${ }^{* * *} p<0.01,{ }^{* *} p<0.05,{ }^{*} p<0.1$

Notes for Tables 5 and 6: Municipal controls include average homicides from 2003 to 2004, population density, average years of schooling, \% of $\mathrm{HH}$ with running water, unemployment in 2010 and 2000, income per capita in 2000,

kilometers of state highways in 2005, and year fixed effects for the panel. State controls include average homicides from 2003 to 2004, population density, annual real GDP per capita and unemployment, non-federal highways in 2005 and year fixed effects

Source: Mexican Census, as accessed through IPUMS, ENOE, INEGI, Colombian Ministry of Defense 
between the instrument and the endogenous variable. Overall the results confirm that federal highways and federal highways interacted with cocaine seizures in Colombia are relevant predictors of which municipalities and states became more violent during the drug war.

\subsection{Second stage results: national migration}

The results for national migration are shown in Table 4. In general we find a muted migration response in our preferred model, which uses time variation. As shown in column 2, which measures migration to another state, we find negative and significant coefficients. This suggests that higher homicides led to a decrease rather than an increase in inter-state migration. When we consider migration to any other location in Mexico, including the same state, we continue to find a negative coefficient (column 4). Although this value is insignificant, the upper bound of the 95\% confidence interval suggests that a two standard deviation increase in annual homicides per 100,000 inhabitants leads to an increase in relocation, either within or across states, of $0.22 \%$. This is low given the scale of increase in violence.

We also find a muted response in the municipal cross section, which is not our preferred model but we include to provide comparison with previous literature. As shown in column 5, the OLS coefficient is positive and significant; a result in line with those from other studies that report a migration response to violence. This conclusion disappears, however, once we control for unobserved regional heterogeneity using the IV model. The IV coefficient becomes statistically insignificant, and, at $0.00596 \%$ suggests that a two standard deviation increase in homicides per 100,000 inhabitants is associated with an increase in out-migration of $0.38 \%$ over a 5 -year period. This value is small given the scale of the increase in violence and time period considered (5 years), and incompatible with a story of large-scale displacement. Overall the results provide little evidence that increasing homicides led to higher domestic migration. ${ }^{29}$

\subsection{Second stage results: international migration}

As shown in Table 5, when we look at international migration rates, the conclusions are slightly different. At the municipal level the results are similar to those for domestic migration, as we find negative coefficients in all cases. This shows that an increase in homicides led to a decrease in the percentage of individuals who move abroad. For example, the coefficient in column 4, which uses the municipal panel, suggests that a one standard deviation increase in violence led international migration to fall by $0.19 \%$. This constitutes a large decline given that average international migration rates are around $0.29 \%$.

What is interesting, however, is that at the state level the IV coefficient is positive and significant (column 2), suggesting that increased violence in the state led more, rather than fewer, individuals to move abroad. ${ }^{3031}$ To reconcile the differences in the municipal- and state-level results, we consider the "perception of insecurity" variable in our theoretical model. As highlighted in the data section, municipalities did not uniformly become more violent, and generally a small number of municipalities drive increased violence at the state level. The result is that in states that became more violent, the variation in violence across municipalities is high (the correlation between 
average violence and the standard deviation is $91 \%$ ), which could lead to different perceptions of insecurity and heterogeneous migration responses. Specifically, the perception of violence could be greater in less violent municipalities in more violent states than in more violent municipalities in these same states. The migration response therefore is greater in less violent municipalities than in more violent ones. This asymmetry in perceptions of violence is similar to Becker and Rubinstein's (2011) analysis of responses to terrorist attacks in Israel. They find that individuals with less exposure to possible attacks react more strongly than those with greater exposure, suggesting they form more exaggerated perceptions of violence. These same differences may explain the gap between the municipal- and state-level results.

Furthermore, there can be data discrepancies between the ENOE and Mexican Census that impact the differences between state and municipality-level responses to violence. As mentioned earlier, the correlation in state-level 5-year aggregate international migration is high across the two data sources, but the correlation is lower for annual state-level migration rates (endnote 17). If the nature of undercounting varies between the datasets, we could be dealing with responses from two different populations. ${ }^{32}$ It is difficult to ascertain the extent to which attrition of households from either sample is correlated with violence.

\section{Robustness checks}

\subsection{Local average treatment effect}

The IV estimates reflect the average impact of homicides for municipalities that become more violent in 2007-2010 as a result of highways within their boundaries. One concern with these local average treatment estimates surrounds the heterogeneity with which highways predict homicides. Some areas may become more violent without having federal highways, or some areas may experience a fall in conflict despite a substantial endowment of highways. If the number of "defier" municipalities is sufficiently large they may cancel the impact of the "complier" municipalities (where presence of highways weakly increased violence or where the lack of highways weakly reduced violence). In order for our results to be representative of all locations that become more violent due to disputes over the distribution networks, the assumptions of monotonicity and independence of the instrumental variable must hold (Imbens and Angrist, 1994). Section 4.1 presents arguments for independence and shows that it was less of a concern when the instrument included time variation. In this section we focus on the requirement of monotonicity for our smallest geographic area- municipalities.

Monotonicity implies that, after controlling for observable characteristics, the coefficient on the highways variable should be weakly positive for all municipalities in the first-stage regressions:

$$
\text { Homicides }_{j}=\alpha_{1}+\alpha_{2, j} \text { InstrumentalVariable } j+M_{j}^{\prime} \theta+e_{j t}
$$

Monotonicity holds even if the impact of highways varies across areas (the $\alpha_{2, j}$ coefficients) as long as they have the same sign. Of course, $\alpha_{2, j}$ cannot be calculated for each geographic unit $j$, and thus some level of aggregation is needed. To do this we place municipalities into quartiles based on the level of predicted homicides. 
We predict annual homicide rates during the 2007-2010 drug war period using all observable controls except federal highway kilometers separately for the subsample of municipalities with highways and no highways. Coefficients for predicted values are calculated from the group of municipalities without highways. It is important to note that $42 \%$ of municipalities have no federal highways. ${ }^{33}$ Predicted homicides are divided into quartiles, and municipalities are assigned accordingly. We then calculate the mean levels of actual homicides by quartile for both categories of municipalities and compare the true and predicted values. The results of this exercise are presented in Fig. 2. Average homicide rates are higher for the municipalities with highways than municipalities with no highways in all cases, except quartile 1. The difference between the two groups rises with the quartile of violence, and the largest difference is seen in quartile 4, providing evidence that the strongest effect is for municipalities with the most highways.

Next, we present results from Eq. (5), but aggregated by quartile of predicted violence in Table 6. The first-stage coefficient on highways is weakly positive for all quartiles, and increasing with the level of violence. This is true for both the municipal crosssectional results in panel A and the municipal panel results in panel B. The effect of the treatment is heterogeneous across quartiles but always non-negative. This lends credence to the belief that defiers are not counteracting the responses of compliers.

\subsection{Falsification tests}

As mentioned previously, we do not include state or municipal fixed effects in our regressions as they would absorb a large portion of the variation used to estimate the relationship between our instrument and homicides. We recognize, however, that despite controls for a number of salient characteristics across states and municipalities, the exclusion restriction will not hold if there are other time-invariant or time-varying factors that are linked to both homicides and migration. We therefore perform several falsification tests to address concerns that our instrument simply captures unobserved,

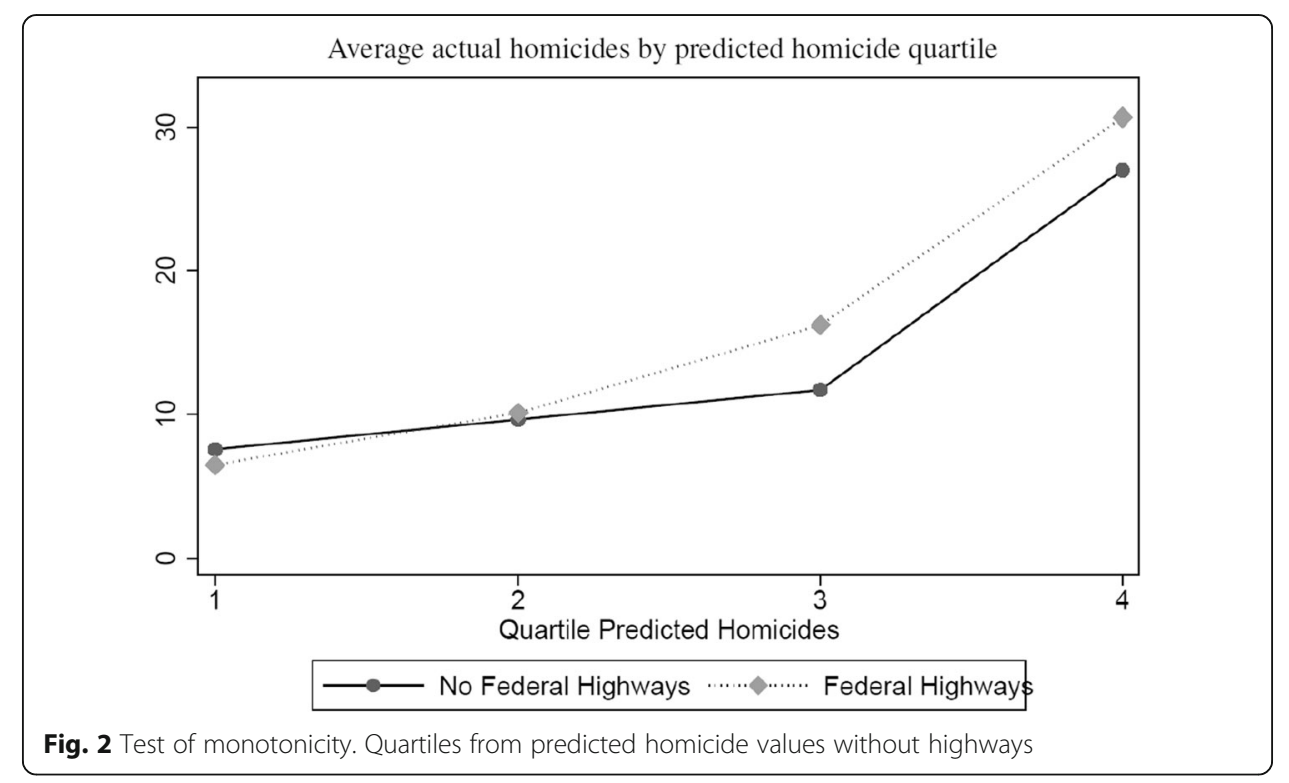




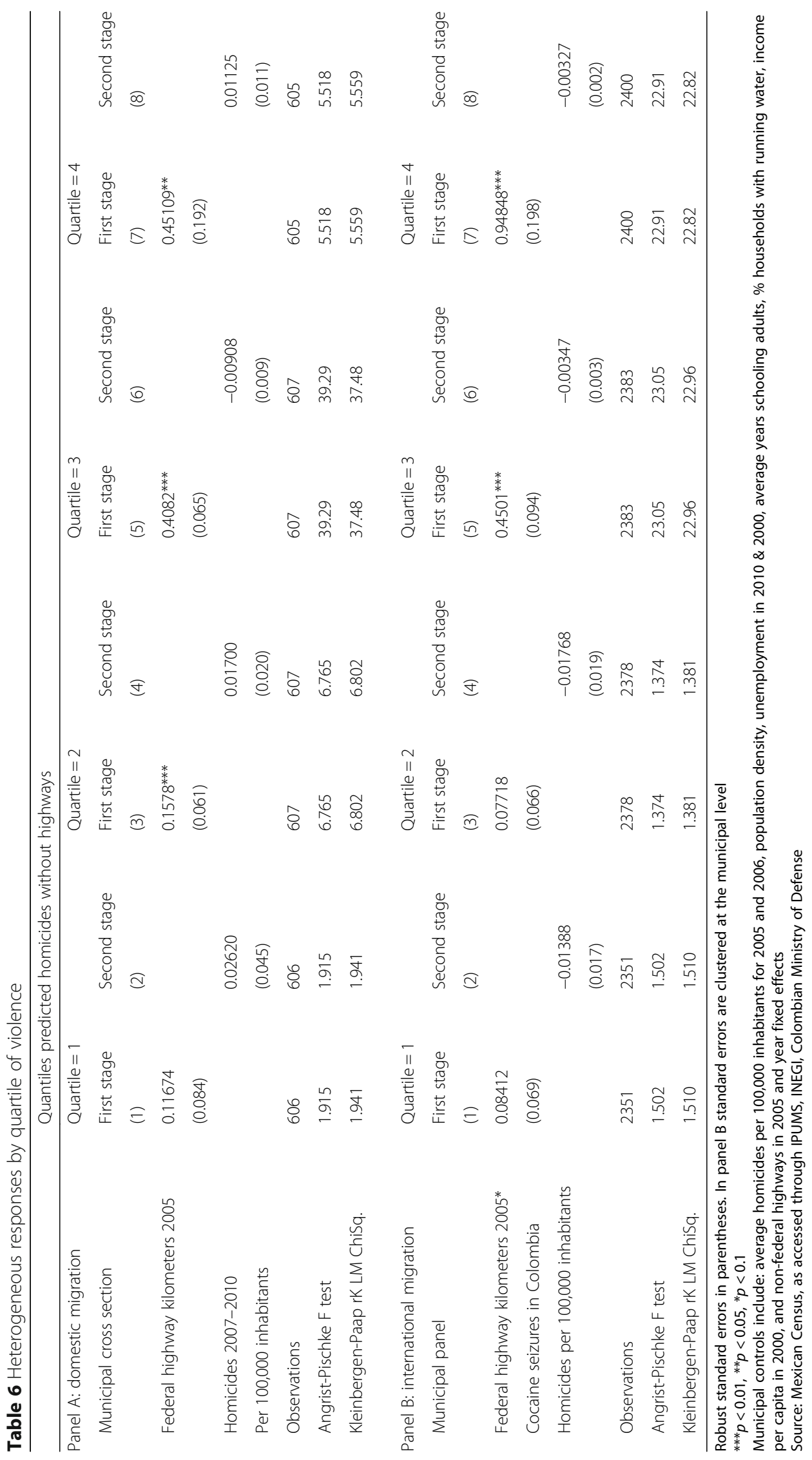


confounding geographic factors rather than differences in the size of drug distribution networks.

First, we argue that if federal highways are simply a proxy for geographic fixed effects, the actual value of the highways should not matter. In this case re-assigning each state or municipality a highway value randomly chosen from another state or municipality should produce results that are similar to our original ones. We test this by randomly assigning highway values to states and municipalities, interacting this with cocaine supply shocks, and re-estimating our first stage. The results are shown in the first column of Table 7. Panels A and B show the results for states and municipalities, respectively, and in both cases we find that randomly assigned highways are very poor predictors of homicides. The coefficients are four (state) and 90 (municipality) times smaller than the original ones and statistically insignificant. We also cannot reject the null hypotheses that the first stage is under and weakly identified. This tells us that the actual value of federal highways matters for predicting homicides.

Second, we argue that if federal highway values capture some underlying confounding factor, like spending on transportation, other measures of transportation networks should also be relevant predictors of homicides. In other words, if federal highways predict highways for a reason other than providing a drug distribution network, other measures of transport, particularly those that are less likely to be used to transport drugs to the USA, should also predict homicides. ${ }^{34}$ We consider two such measures: kilometers of state highways, and airports, as measured by square kilometers of runways and square kilometers of airport platforms in national and international airports

Table 7 Falsification tests

\begin{tabular}{|c|c|c|c|c|}
\hline \multicolumn{5}{|l|}{ Panel A: first stage results, state panel } \\
\hline Alternative transport network measure & $\begin{array}{l}\text { Random federal } \\
\text { highways }\end{array}$ & $\begin{array}{l}\text { Airport } \\
\text { runways }\end{array}$ & $\begin{array}{l}\text { Airport } \\
\text { platforms }\end{array}$ & $\begin{array}{l}\text { State } \\
\text { highways }\end{array}$ \\
\hline Outcome variable $=$ homicides & $(1)$ & $(2)$ & (3) & (4) \\
\hline Transport measure $2005^{*}$ & 0.00885 & -0.04195 & -0.12049 & 0.00034 \\
\hline Cocaine seizures in Colombia & $(0.00850)$ & $(0.05134)$ & $(0.08154)$ & $(0.00118)$ \\
\hline Observations & 224 & 224 & 224 & 224 \\
\hline Angrist-Pischke $F$ test & 1.085 & 0.668 & 2.184 & 0.0845 \\
\hline $\begin{array}{l}\text { Anderson-Rubin LM } \\
\text { ChiSquared }\end{array}$ & 1.146 & 0.706 & 2.295 & 0.0892 \\
\hline \multicolumn{5}{|l|}{ Panel B: first stage results, municipal panel } \\
\hline Alternative transport network measure & Random federal highways & & & \\
\hline Outcome variable $=$ homicides & $(1)$ & & & \\
\hline Transport measure $2005^{*}$ & -0.02361 & & & \\
\hline Cocaine seizures in Colombia & $(0.02739)$ & & & \\
\hline Observations & 14,262 & & & \\
\hline Angrist-Pischke $F$ test & 0.743 & & & \\
\hline Anderson-Rubin LM ChiSquared & 0.704 & & & \\
\hline
\end{tabular}


as of 2005. Note that we measure airports at the state level only, given that there are only 61 as of 2005 , which means the majority of municipalities have zero values. We re-estimate the first-stage equations using these alternative transportation network measures interacted with Colombian cocaine supply shocks as our instrumental variables. The results are shown in columns 2 through 4 of panel A of Table 7. We find that airports and state highways are poor predictors of homicides, as the coefficients either have the opposite sign, in the case of airports, or have the same size but are a tenth of the size of the original, in the case of state highways. The coefficients are statistically insignificant and $F$ and $\chi^{2}$ values are well below the threshold for reject the null of an under and weakly identified first stage. These results support our argument that our original instrument captures changes to the value of drug distribution networks over time, rather than other unobservable time-varying factors that predict both migration and violence.

\subsection{Migration dynamics}

In this section we explore the dynamics of migration in more detail. In particular, we explore the possibility that people's perceptions about violence and the benefits of moving may be driven by previous rather than contemporaneous homicides. This is likely if people are more likely to respond to increases in violence they view as permanent rather than temporary, and lagged values can better capture the former rather than the latter. We therefore consider a one- and two-period lag in the relocation response, by estimating the interacted IV model, instrumenting for lagged homicides using kilometers of federal highways in 2005 multiplied by cocaine seizures in the previous year or two periods. All other controls remain the same.

The results for domestic migration are shown in panel A of Table 8, while the results for international migration are shown in panel B. In general they are similar to the initial results. We find a negative and significant effect of lagged homicides on domestic migration at the state level, a negative but insignificant effect of homicides on international migration at the municipal level, but a positive and significant effect of homicides on international migration at the state level. Thus considering lagged violence our conclusions about the migratory response do not change.

\section{Conclusions}

In this paper we investigate if the large increase in homicides that took place in Mexico after the start of the drug war led to increased migration, both to other parts of Mexico and abroad. To identify the relationship between violent death and migration rates at the municipal and state level, we instrument for the violence using kilometers of federal highways interacted with shocks to the cocaine supply from Colombia. We argue that federal highways capture pre-existing drug distribution networks, a key asset driving the dissent among cartels, and between cartels and the federal government, and the interacted instrument captures the variation to the value of these networks over time. After controlling for observable and unobservable area level characteristics, we find little evidence that homicides related to the drug war led to increased domestic migration. We also find little evidence of increased international migration at the municipal level, but some evidence of increased migration at the state level. While we cannot 
Table 8 Robustness checks: lagged crime and migration patterns

\begin{tabular}{|c|c|c|c|c|}
\hline \multicolumn{5}{|l|}{ Panel A: domestic migration } \\
\hline 2nd stage IV results & \multicolumn{4}{|c|}{ State level panel (annual) } \\
\hline \multirow[t]{2}{*}{ Migration type } & \multicolumn{2}{|c|}{ Another state } & \multicolumn{2}{|c|}{ Anywhere in Mexico } \\
\hline & (1) & $(2)$ & (3) & $(4)$ \\
\hline \multirow[t]{2}{*}{ Homicides, 1-year lag } & \multicolumn{2}{|l|}{$-0.00758^{*}$} & \multicolumn{2}{|l|}{-0.01709} \\
\hline & \multicolumn{2}{|l|}{$(0.00401)$} & \multicolumn{2}{|l|}{$(0.01070)$} \\
\hline \multirow[t]{2}{*}{ Homicides, 2-year lag } & \multicolumn{3}{|c|}{$-0.01132^{* *}$} & -0.02268 \\
\hline & \multicolumn{3}{|c|}{$(0.00524)$} & $(0.01423)$ \\
\hline Observations & 192 & 160 & 192 & 160 \\
\hline Angrist-Pischke $F$ test & 7.975 & 10.21 & 7.975 & 10.21 \\
\hline Anderson-Rubin LM ChiSquared & 8.145 & 10.26 & 8.145 & 10.26 \\
\hline \multicolumn{5}{|l|}{ Panel B: international migration } \\
\hline \multirow[t]{2}{*}{ Geographic and time variation } & \multicolumn{2}{|c|}{ Municipal panel (annual) } & \multicolumn{2}{|c|}{ State panel (annual) } \\
\hline & (1) & $(2)$ & (3) & $(4)$ \\
\hline \multirow[t]{2}{*}{ Homicides, 1-year lag } & \multicolumn{2}{|l|}{$-0.00703^{* *}$} & \multicolumn{2}{|l|}{$0.00495^{*}$} \\
\hline & \multicolumn{2}{|l|}{$(0.00284)$} & \multicolumn{2}{|l|}{$(0.00267)$} \\
\hline \multirow[t]{2}{*}{ Homicides, 2-year lag } & & $-0.01096^{* *}$ & & $0.00573^{*}$ \\
\hline & & $(0.00451)$ & & $(0.00310)$ \\
\hline Observations & 11,890 & 9512 & 192 & 160 \\
\hline Angrist-Pischke $F$ test & 12.47 & 10.49 & 7.975 & 10.21 \\
\hline Anderson-Rubin LM ChiSquared & 17.20 & 12.96 & 8.145 & 10.26 \\
\hline
\end{tabular}

account for entire families that moved abroad, our results generally are inconsistent with anecdotal accounts of wide-scale displacement as a result of the drug war, as well as cross-sectional or panel-data estimates of the effect of violence on migration in Mexico that fail to account for time-variant heterogeneity across regions.

Several factors may explain the lack of relocation response in the face of largescale violence. First, the Mexican population is not particularly mobile. Domestic migration rates were low prior to the commencement of the drug war and have fallen further since. Second, migration is a costly response to violence, and people may change their labor market and household savings and investment decisions to adapt to insecurity. Violence may additionally dampen the incentives to move by increasing tenure insecurity regarding fixed assets like land and reducing property values. Third, the drug war coincided with macroeconomic events that reduced the incentives to move abroad, particularly to the USA. The Great Recession combined with increased border security made migration to the USA costlier, and it is possible that in the absence of the conflict net flows would have fallen even further. Finally, inaccuracies in the perceptions of violence across different locations in Mexico may deter domestic migration. National surveys reveal weak correlations between actual and perceived increases in violence at the state level, which may 
lead people to think that moving domestically will not lead to an appreciable increase in safety. For all of these reasons, even though life has become difficult in some areas as a result of the drug war, the average individual may find moving to be too costly.

Finally, our analysis is positive rather than normative in nature. We find that people largely do not relocate in response to large increases in violence, but it could be the case that if the costs were lower or if people had accurate perceptions of violence in the home and destination locations, migration would be the optimal adjustment mechanism. Without more information on alternative responses or the extent to which information and monetary barriers limit migration, it is impossible to know if the decision to stay in increasingly violent areas is first or second best. We also do not attempt to measure the total welfare cost of the violence, or the extent to which welfare could be improved by relocation, but view such analysis as fruitful, particularly for policy makers attempting to improve individuals' ability to manage higher levels of violence. Further work on how people form perceptions of violence and the ways in which they adapt are necessary to perform a welfare exercise and further our understanding of the total societal costs of violence.

\section{Endnotes}

${ }^{1}$ Homicide data from municipal death records, accessed through Mexico's statistical agency, Instituto Nacional de Estadística y Geografía or INEGI (www.inegi.org.mx).

${ }^{2}$ Author's calculations from the National Survey of Insecurity (ENSI). Data and documentation are available on INEGI's website.

${ }^{3}$ In addition, the casualties have spread beyond the combatants (members of the cartels, police and army) to the civilian population. While comprehensive data on the victims of drug-related violence is not available, analysis of a subsample of drug-related crimes reported in newspapers between 2006 and 2012 provides an idea of the civilian cost (the Violence and Victims Monitor dataset, compiled by the Trans-border Institute). Of the 3052 cases analyzed, the authors estimate that $1.5 \%$ of the victims are current or former mayors, while $2.4 \%$ are journalists or media support workers (Molzahn et al. 2013). Applied to all drug-related deaths, these numbers suggest the civilian cost is not small.

${ }^{4}$ The authors examine the responses of Israelis to terror attacks during the "Al-Aqsa" Intifada. Occasional users of transportation services and coffee shops decrease their usage, but not frequent users. This suggests that more frequent users of services form more accurate perceptions of the true level of violence.

${ }^{5}$ Márquez-Padilla et al. 2015, while studying the effect of drug violence on school enrollment in Mexico also find population declines, for various segments by age and gender, in response to violence.

${ }^{6}$ Another exception is Velásquez (2015) who finds that violence has increased migration for certain sub-populations. She corrects for time-invariant characteristics using a panel data set of individuals, but the strategy does not allow for the control of variables that change over time and affect migration and violence. 
${ }^{7}$ The role of selection into migration in determining education outcomes is explored, although it is likely that the lack of education opportunities in an area causes households to move out (Márquez-Padilla et al. 2015).

${ }^{8}$ In the municipal death records missing data and no homicides are coded in the same way, since municipalities without homicides in a given year do not appear. To distinguish between non-response and zero values we use information on all deaths, either from homicides or other causes. We assume if a municipality reports values for all deaths but not homicides, there were no homicides and the value is zero. If a municipality does not report values for all deaths or homicides, we assume the information is missing and code the value as a non-response.

${ }^{9}$ We also consider drug-related homicides from Mexico's National Security Council (SESNSP) as our measure of homicides. These are available from December 2006 to September 2011, but given the lack of data on drug-related homicides prior to the drug war- a measure of pre-existing violence- we view these results as secondary. They are available upon request.

${ }^{10}$ We use the 2005 CONAPO projections because the 2010 projections, adjusted after the 2010 Census was complete, do not include revisions of earlier years.

${ }^{11}$ The homicide variable is calculated as a proportion of the area's. population. Population is naturally higher when aggregated across municipalities in a state. Not all municipalities within a state need to be similarly violent. Hence the range for homicides is lower in panel B.

${ }^{12}$ In 2010, the overall homicide rate for the USA was 5.27 per 100,000 people which was slightly lower than the comparable Hispanic homicide rate of 5.73 (Violence Policy Center, 2014). The Federal Bureau of Investigation's Uniform Crime Reporting Statistics for 2010 indicate homicide rates of 4.9, 6.4, 6.9 and 5 (per 100,000 people) for the four border states of California, Arizona, New Mexico and Texas. Similar statistics for years preceding 2010 also indicate that the USA overall, and the border states specifically, are less violent than the average Mexican state or municipality (as seen in Table 1).

${ }^{13}$ Since our focus is migration decisions of individuals exposed to violence in Mexico, we remove individuals who lived outside the country 5 years ago. This means return migrants are not considered in the analysis.

${ }^{14}$ ENOE stands for the Encuesta Nacional de Ocupación y Empleo. The data and documentation for the ENOE are available on the INEGI website. www.inegi.org.mx

${ }^{15} \mathrm{We}$ are unaware of any panel data set that is representative at the municipal or other geographic levels besides the ENOE that is representative at the state level. Panel data sets like the Mexican Family Life Survey, are only representative at the regional level, as defined in accordance with the National Development Plan 20002006. This is a level of geographic aggregation that is much higher than the state, and therefore does not provide sufficient variation in violence to assess differences in possible migration responses.

${ }^{16}$ We recognize concerns that the gross migration rate may not accurately capture relocation responses if there is a high correlation between out- and inmigration. If this is the case gross migration may not accurately reflect population outflows, as out migrants are replaced by in migrants. To check this we calculate a 
net 5-year migration rate from the Census, which does include information on where people moved to domestically. The correlation between the two measures is high, alleviating concerns that the gross migration rate does not reflect population movements. In the 2010 Census the correlation between the gross and net domestic migration rate is 0.794 , while in the 2000 Census the correlation is 0.8598 .

${ }^{17} \mathrm{We}$ calculate state level international migration rates from the Census to gauge differences between the Census and ENOE. For the 5-year migration rate, the correlation across the two data sources is $92.1 \%$. For the annual migration rate, the correlation is $56.6 \%$. This suggests the total number of international migrants over the 5 -year period recorded by both data sets is similar, but that some discrepancy exists in recorded year of departure.

${ }^{18}$ For example, it is believed that Mexico took over Colombia's place as the major distributor of drugs to the USA in 1994. This was a result of the USA's efforts to close off the Caribbean routes into the USA (through Miami) and increased trade flows between Mexico and the USA due the signing of NAFTA.

${ }^{19}$ No breakdown is available, but person transport via rail in Mexico is low. The reliance on highways for transport largely is due to the poor state of Mexico's railroads, which only recently have improved under private concessions.

${ }^{20}$ Federal highways consist of free highways, for which no toll is charged, and toll highways. The data come from the 2005 Annual Reports for each state. For two states (Puebla and Oaxaca) it was necessary to impute values at the municipal level. The imputation was done using data on registered passenger trucks from the Annual Reports for each state.

${ }^{21}$ In the National Drug Threat Assessment, the U.S. Department of Justice (2010) states that most drugs are smuggled into the USA over land, and not via the sea or air. The report also talks about major corridors for trafficking within the USA, all of which are along highway routes.

${ }^{22}$ In an earlier year (2000) Colombia was estimated to produce $79 \%$ of the world's cocaine supply.

${ }^{23}$ Mexico is a producer of opium and marijuana, two other drugs whose production and transport make up a portion of drug trafficking organizations profits. To measure the production of these drugs we use data on seizures from the Mexican Defense Ministry (SEDENA). Seizures are the best available proxy measures for production in absence of regular estimates from satellite images. To see if production is a strong predictor of violence we test for a correlation between Mexican seizures and violence using quarterly data on all homicides from the period of Q12005 to Q42011. We find no significant correlation between opium seizures and homicides and a negative and significant correlation between marijuana seizures and homicides. Thus changes to the supply of opium and marijuana in Mexico do not appear to be strongly associated with changes in violence.

${ }^{24}$ We are grateful to Juan Camilo Castillo for providing us with these data. We use total tons of cocaine seized by Colombia authorities rather than an estimate of total cocaine production as the latter depends upon estimates of potential cocaine production, which come from the United Nations Office on Drugs and Crime. In the 2013 World Drug Report, UNODC notes that due to a new adjustment factor for small fields the estimated figures for 2010 and 2011 are not comparable to 
those from earlier years. The 2010 estimate shows a significant decline from earlier years. As a result, we use seizure data, which is more consistent over the 20052010 time period we consider.

${ }^{25}$ Quarterly data on employment rates, unemployment rates and weekly hours worked from the ENOE. Quarterly real GDP values in 2008 pesos from INEGI.

${ }^{26}$ Indeed, federal highways make up only $20 \%$ of all highway kilometers as of 2005, which means that state highways should capture a large degree of the timeinvariant migration costs associated with a road network.

${ }^{27}$ Unemployment rates, years of education, income in 2000 , the number of households with running water and previous migration rates are constructed by the authors from the 2000 and 2010 Census. The state highway variable comes from the state statistical abstracts provided by INEGI. Population density is calculated using information on square kilometers as of the year 2005 from INEGI and population as of the same year from CONAPO. We also remove 2 municipalities with national out migration rates in excess of $50 \%$ in 2010.

${ }^{28}$ For annual international migration we cluster standard errors at the municipal level. We do not cluster standard errors for the state-level models as there are only 32 states, below the number needed for the clustered standard errors to be unbiased (Angrist and Pischke 2009, Kezdi 2004).

${ }^{29}$ To further address concerns about net migration we estimate the instrumental variables model on two other outcome variables. First, we use net migration for the municipal cross section, and find similar results to those that use gross migrations. The IV coefficient on the 5-year net migration rate is -0.0009 and insignificant. Second, we use the population of 18 to 65 year olds at the state level from the ENOE (calculated in the first quarter of each year). The IV coefficient on population is negative, but small and insignificant. This suggests our results are robust to the consideration of in-migration. The full results of both robustness checks are available upon request.

${ }^{30} \mathrm{We}$ also get positive coefficients if we limit the years to 2007 to 2010 or if we use annual international migration flows from the Census rather than the ENOE. Thus the discrepancy in the state and municipal results is not due to the time frame or deviations in the recorded year of migration in the ENOE.

${ }^{31}$ The results persist if we include controls for municipalities or states that lie on the USA-Mexico border. Hence the differences are not due to heterogeneous responses to violence and migration from proximity to the USA.

${ }^{32}$ The extent of undercounting is likely to be higher in the Census compared to the ENOE. For example, in ENOE 2010, an average of 3.5\% households were seen to leave the sample between rounds. It was unclear whether this was due to international or internal migration. To partially gauge the extent of missing households in the Census, we consider the number of new Mexican immigrants in the USA with multiple family members over the drug war period. One-fourth had three or more family members, of which at least one was a child. This constitutes an increase from the previous 10-year period average of $20 \%$.

${ }^{33}$ There are no states in Mexico without federal highways, hence this exercise is done only at the municipal level.

${ }^{34}$ The National Drug Threat Assessment Report of 2010 contends that drugs from Mexico to the USA are rarely smuggled by air. 


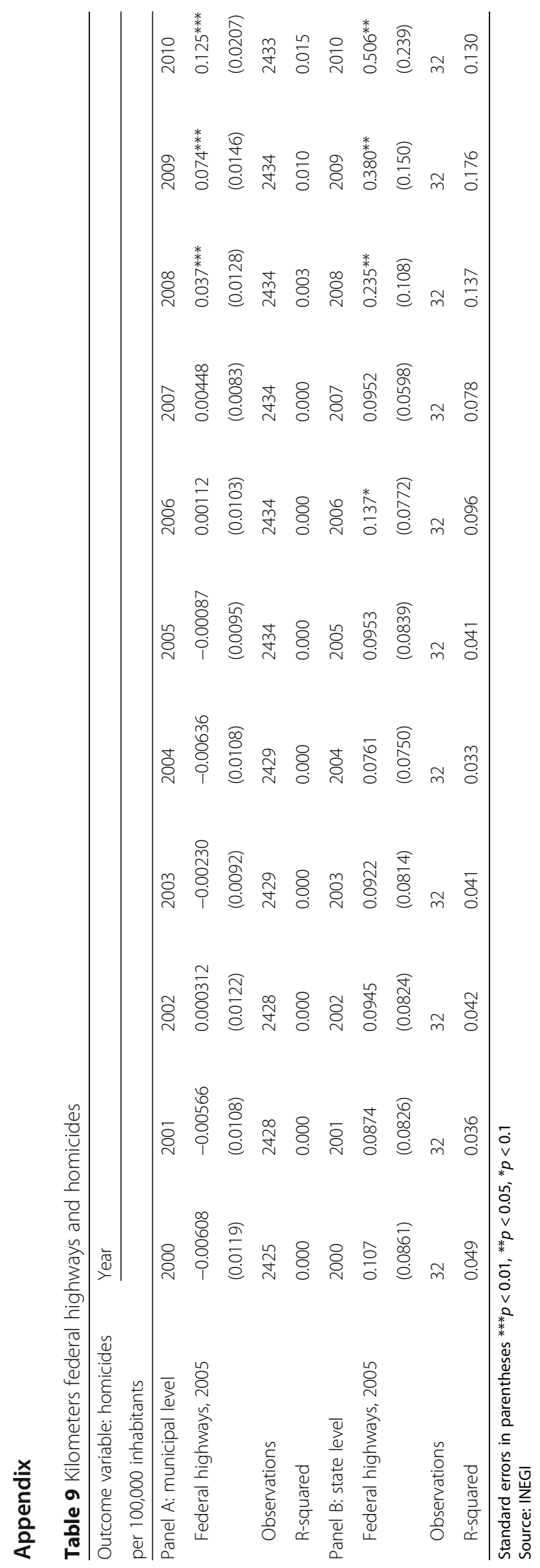


Table 10 Cocaine seizures in Colombia and other economic variables in Mexico or the USA

\begin{tabular}{|c|c|c|c|c|c|}
\hline \multirow[t]{2}{*}{ Panel A: exports } & \multicolumn{3}{|c|}{ Colombia, exports } & \multicolumn{2}{|l|}{ Mexico, exports } \\
\hline & Mexico & United States & World & United States & World \\
\hline Monthly data, January 2004-April 2012 & (1) & (2) & (3) & (4) & (5) \\
\hline Cocaine seized by Colombian & 82.65166 & 0.44371 & 0.39775 & -0.03587 & 0.00789 \\
\hline Authorities & $(66.98469)$ & $(1.65411)$ & $(0.65803)$ & $(0.22173)$ & $(0.15651)$ \\
\hline Observations & 100 & 100 & 100 & 100 & 100 \\
\hline R-squared & 0.01530 & 0.00073 & 0.00371 & 0.00027 & 0.00003 \\
\hline \multicolumn{6}{|l|}{ Panel B: economic activity } \\
\hline & Employment & Unemployment & Weekly & \multirow{2}{*}{\multicolumn{2}{|c|}{ Real GDP }} \\
\hline & & & hours worked & & \\
\hline Quarterly data, Q12005-Q42011 & (1) & (2) & (3) & \multicolumn{2}{|l|}{ (4) } \\
\hline Cocaine Seized by Colombian & -0.00003 & 0.00005 & -0.00339 & \multicolumn{2}{|l|}{-0.00344} \\
\hline Authorities & $(0.00009)$ & $(0.00008)$ & $(0.00682)$ & \multicolumn{2}{|l|}{$(0.00779)$} \\
\hline Observations & 28 & 28 & 28 & \multicolumn{2}{|l|}{28} \\
\hline R-squared & 0.00326 & 0.01545 & 0.00939 & \multicolumn{2}{|l|}{0.00745} \\
\hline \multicolumn{6}{|l|}{ Panel C: drug seizures by } \\
\hline Mexican authorities & Opium & \multicolumn{4}{|l|}{ Marijuana } \\
\hline Quarterly data, Q12005-Q42011 & (1) & \multicolumn{4}{|l|}{ (2) } \\
\hline Cocaine seized by Colombian & -0.13952 & \multicolumn{4}{|l|}{-0.20048} \\
\hline Authorities & $(0.16537)$ & \multicolumn{4}{|l|}{$(0.17662)$} \\
\hline Observations & 28 & \multicolumn{4}{|l|}{28} \\
\hline R-squared & 0.02665 & \multicolumn{4}{|l|}{0.04722} \\
\hline \multicolumn{6}{|c|}{$\begin{array}{l}\text { Standard errors in brackets. }{ }^{* * *} p<0.01,{ }^{* *} p<0.05,{ }^{*} p<0.01 \\
\text { Data on Exports in millions of US dollars. Cocaine seizures in tons } \\
\text { Monthly data on exports from January } 2004 \text { to April } 2012 \text { from the IMF, Direction of Trade Statistics } \\
\text { Monthly data on cocaine seizures from the Colombian Ministry of Defense } \\
\text { Quarterly data on employment, unemployment and weekly hours worked from the ENOE. Quarterly data on real GDP in } \\
2008 \text { pesos from INEGI } \\
\text { Quarterly data on seizures of opium and marijuana from SEDENA }\end{array}$} \\
\hline
\end{tabular}

a

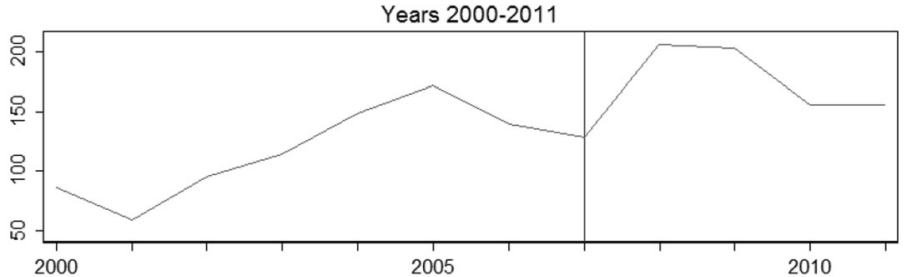

b

Years $2000-2011$

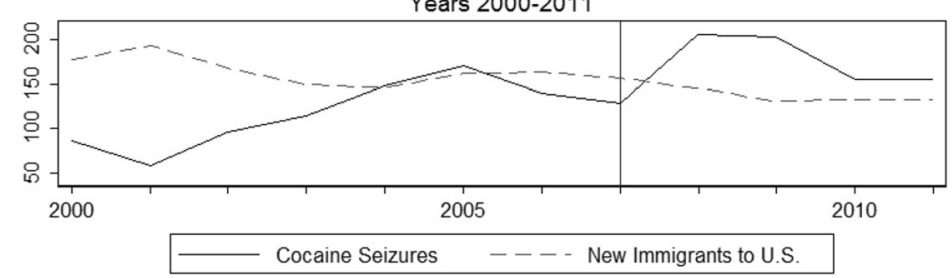

Note: The correlation between annual cocaine seizures in Colombia and new Mexican immigrants to the U.S. is -0.79 .

Fig 3 Cocaine seizures in Colombia: 2000-2011. a Annual Changes in Thousands of Tons. b Cociane Seizures in Colombia (thousands of tons) \& New Mexican Immigrants to the U.S (tens of thousands). Source: Colombia Defense Ministry and American Community Surveys 


\section{Acknowledgements}

We are grateful to the Ford Foundation for funding for this project. We also are grateful to Claire Oxford for excellent research assistance, Juan Trejo for assistance with the Mexican Census data, Juan Camilo Castillo and Daniel Mejia for providing the Colombian cocaine seizure data, and seminar participants at Vassar College, Bates College, Wake Forest University, University of Rochester, ITAM, University of Connecticut and LAC-DEV for feedback. We would also like to thank the anonymous referee and the editor for the useful remarks. All remaining errors are our own. Responsible editor: Jackline Wahba

\section{Competing interests}

The IZA Journal of Development and Migration is committed to the IZA Guiding Principles of Research Integrity. The authors declare that they have observed these principles.

\section{Publisher's Note}

Springer Nature remains neutral with regard to jurisdictional claims in published maps and institutional affiliations.

Received: 12 May 2017 Accepted: 12 May 2017

Published online: 09 November 2017

\section{References}

Abadíe A, Gardeazábal J. The Economic Costs of Conflict: A Case Study of the Basque Country. Am Econ Rev. 2003;93(1):113-32.

Aguayo-Téllez E, Martínez-Navarro J. Internal and International Migration in Mexico: 1995-2000. Appl Econ. 2012;45(13):1647-61.

Alvarado S, Massey D. In Search of Peace: Structural Adjustment, Violence, and International Migration. Ann Am Acad Pol Soc Sci. 2010;630(1):137-61.

Arceo-Gómez EO. Drug-Related Violence, Forced Migration and the Changing Face of Mexican Immigrants in the United States, Working Paper, Centro de Investigación y Docencia Económicas. 2013. http://digitalcommons.fiu. edu/cgi/viewcontent.cgi?article=1009\&context=ippcs_colloquia.

Becker GS, Rubinstein Y. Fear and the Response to Terrorism: An Economic Analysis, Centre for Economic Performance Discussion Paper No. 1079. 2011.

Bell M, Muhidin S. Cross-National Comparison of Internal Migration, Human Development Research Paper (HDRP) Series 30. 2009.

Bohra-Mishra P, Massey DS. Individual Decisions to Migrate During Civil Conflict. Demography. 2011;48(2):401-24.

Borjas GJ. Self-Selection and the Earnings of Immigrants. Am Econ Rev. 1987;77(4):531-53.

Borjas GJ. The Economic Analysis of Immigration. In: Ashenfelter O, Card D, editors. Handbook of Labor Economics, vol. 3A. 1999.

Braakmann N. How do Individuals Deal with Victimization and Victimization Risk? Longitudinal Evidence from Mexico. J Econ Behav Organ. 2012;84(1):335-44.

Castillo JC, Restrepo P, Mejía D. Scarcity Without Leviathan: The Violent Effects of Cocaine Supply Shortages in the Mexican Drug War. 2016. Working paper.

Congressional Research Service Report for Congress (2013) by Clare Ribando Seelke. Mexico's Peña Nieto Administration: Priorities and Key Issues in U.S.-Mexican Relations. Report: https:/www.files.ethz.ch/isn/159659/213989.pdf

Cullen JB, Levitt SD. Urban Flight and the Consequences for Cities. Rev Econ Stat. 1999;81(2):159-69.

Davenport C, Moore W, Poe S. Sometimes You Just Have to Leave: Domestic Threats and Refugee Movements, 1964-1989. Int Interact. 2003;29(1):27-55.

De Mello J, Zilberman E. Does Crime Affect Economic Decisions? An Empirical Investigation of Savings in a High-Crime Environment. BE J Econ Anal Policy. 2008;8(1):Article 52.

Dell M. Trafficking Networks and the Mexican Drug War. Am Econ Rev. 2015;105(6):1738-79.

Dube O, Ponce OG, Thom K. From Maize to Haze: Agricultural Shocks and the Growth of the Mexican Drug Sector. In: Center for Global Development, Working Paper 355. 2014.

Dugan L. The Effect of Criminal Victimization on a Household's Moving Decision. Criminology. 1999;37(4):903-30.

Engel S, Ibáñez A. Displacement due to violence in Colombia: A household level analysis. Econ Dev Cult Chang. 2007;55(2):335-65.

Gibbons S. The Costs of Urban Property Crime. Econ J. 2004;114(499):F441-63.

Guerrero-Gutiérrez E. Security, Drugs and Violence in Mexico: A Survey. Paper presented at the 7th North American Forum, Washington D.C.; 2011

Hirschman AO. Exit, Voice, and Loyalty: Responses to Decline in Firms, Organizations, and States. Cambridge: Harvard University Press; 1970.

Ihlanfeldt K, Moyock T. Panel Data Estimates of the Effects of Different Types of Crime on Housing Prices. Reg Sci Urban Econ. 2010;40(2-3):161-72.

Imbens G, Angrist J. Identification and Estimation of Local Average Treatment Effects. Econometrica. 1994;62(2):467-75

Internal Displacement Monitoring Centre. Mexico: Displacement due to Criminal and Communal Violence. Mimeograph, Norwegian Refugee Council; 2011. Report at: http://www.internal-displacement.org/assets/library/ Americas/Mexico/pdf/201110-am-mexico-overview-en.pdf

Kezdi G. Robust Standard Error Estimation in Fixed-Effects Panel Models. Hungarian Stat Rev Spec. 2004;9:221-33.

Kilmer B, Caulkins JP, Bond BM, Reuter PH. Reducing Drug Trafficking Revenues and Violence in Mexico: Would Legalizing Marijuana in California Help? RAND Occasional Paper 325. 2010.

Márquez-Padilla F, Pérez-Arce F, Rodríguez-Castelán C. The (Non-) Effect of Violence on Education: Evidence from the "War on Drugs" in Mexico. In: World Bank Poverty Global Practice Group, Policy Research Working Paper 7230. 2015.

Michaelsen M, Salardi P. Violence, Psychological Stress and Educational Performance in Mexico. San Diego: Pacific Conference for Development Economics, University of California San Diego; 2015. 
Molzahn C, Rios V, Shirk DA. Drug Violence in Mexico: Data and Analysis Through 2011. Trans-Border Institute, Special Report; 2012

Moore W, Shellman S. Fear of Persecution: Forced Migration 1952-95. J Confl Resolut. 2004;40(5):723-45.

Morrison AR. Violence or Economics: What Drives Internal Migration in Guatemala?". Econ Dev Cult Chang. 1993;41(4):817-31.

Orraca Romano P. Crime Exposure and Educational Outcomes in Mexico. University of Sussex, Department of Economics, Mimeo; 2015.

Passel J, Cohn D, Gonzalez-Barrera A. Net Migration from Mexico Falls to Zero- and Perhaps Less. Washington D.C.: The Pew Hispanic Center; 2012.

Rice A. Life on the Line. New York Times; 2011. http://www.nytimes.com/2011/07/31/magazine/life-onthe-line-betweenel-paso-and-juarez.html.

Rios V. Why Did Mexico become so violent? A self-reinforcing violent equilibrium caused by competition and enforcement. Trends in Organized Crime. 2012;16(2):138-55.

Rios V. The Role of Drug-Related Violence and Extortion in Promoting. Mexican Migration: Unexpected Consequences of a Drug War. Lat Am Res Rev. 2014;49(3):199-217.

Rios V, Shirk DA. Drug Violence in Mexico: Data and Analysis Through 2010. Trans-Border Institute, Special Report; 2011. Report available at https://justiceinmexico.files.wordpress.com/2011/03/2011-tbi-drugviolence.pdf.

Robles G, Calderón G, Magaloni B. The Economic Consequences of Drug Trafficking Violence in Mexico. mimeo, Poverty and Governance, Stanford University. 2013. Paper available at https://cddrl.fsi.stanford.edu/sites/default/ files/RoblesCalderonMagaloni_EconCosts5.pdf.

Rodriguez C, Villa E. Kidnap risks and migration: evidence from Colombia. J Popul Econ. 2012;25:1139-64.

Trans-Border Institute Report. The Drug War in Mexico U.S.-Mexico Security Challenges in 2013 and Beyond. In: Joan B, editor. Kroc School of Peace Studies University of San Diego. 2012. Report available at http://catcher.sandiego.edu/ items/peacestudies/Shirk-Mexico\%20Security-sm.pdf.

U.S. Department of Justice, National Drug Intelligence Center. National Drug Threat Assessment, February 2010. Online report accessed: https://www.justice.gov/archive/ndic/pubs38/38661/38661 p.pdf

United Nations Office on Drugs and Crime (UNDOC). The World Drug Report, 2010. United Nations publications. New York. https://www.unodc.org/unodc/en/data-and-analysis/WDR-2010.html

Valsecchi M. Land property rights and international migration: Evidence from Mexico. J Dev Econ. 2014:110:276-290. https://doi.org/10.1016/j.jdeveco.2014.01.010.

Velásquez A. The Economic Burden of Crime: Evidence from Mexico. University of Colorado Denver, Department of Economics, Mimeo; 2015. https://www.dropbox.com/s/z2hvdwgi57r9laa/Crime-Velasquez_June2015.pdf?dl=0.

Verwimp P, Justino P, Tilman Brück, Mathias Czaika, Krisztina Kis-Katos, (2009) Civil Conflict and Displacement: VillageLevel Determinants of Forced Migration in Aceh. Journal of Peace Research 46 (3):399-418.

Wood CH, Gibson CL, Ribeiro L, Hamsho-Diaz P. Crime Victimization in Latin America and Intentions to Migrate to the United States. Int Migr Rev. 2010;44(1):3-24.

Xie M, McDowall D. Escaping Crime: The Effects of Direct and Indirect Victimization on Moving. Criminology. 2008;46(4):809-40

\section{Submit your manuscript to a SpringerOpen ${ }^{\circ}$ journal and benefit from:}

- Convenient online submission

- Rigorous peer review

Open access: articles freely available online

- High visibility within the field

- Retaining the copyright to your article 